\title{
Balance study of twenty trace elements during total parenteral nutrition in man
}

\author{
By S. JACOBSON* AND P.-O. WESTER \\ Departments of Surgery and Medicine, Serafimerlasarettet, and \\ Nutrition Unit, Karolinska Institute, Stockholm, Sweden
}

(Received 23 February I976-Accepted I2 March 1976)

\begin{abstract}
1. Balances of twenty trace elements (silver, arsenic, gold, bromine, cadmium, cobalt, chromium, caesium, copper, iron, mercury, lanthanum, molybdenum, rubidium, antimony, scandium, selenium, samarium, tungsten and zinc) have been determined in four male patients during total parenteral nutrition including fat emulsion and a special solution for addition of $\mathrm{Fe}, \mathrm{Zn}$, manganese, $\mathrm{Cu}$, fluorine and iodine, besides calcium and magnesium, to the infusion solutions.

2. The analyses for trace elements were made with the aid of an ion-exchange technique based on neutron activation, and combined with subsequent gamma spectrometry.

3. The intended intravenous supply of trace elements corresponded approximately to the analysed supply. However, all the other trace elements determined were found to be unintentionally administered in small amounts.

4. There was a substantial retention of $\mathrm{Fe}$. Other elements retained were $\mathrm{Ag}, \mathrm{Co}, \mathrm{Cr}, \mathrm{Cu}$, $\mathrm{Sb}, \mathrm{Sc}$ and $\mathrm{W}$.

5. Particularly $\mathrm{Br}$ and $\mathrm{Rb}$ were lost by the patients, but negative balances were also found for $\mathrm{As}, \mathrm{Au}, \mathrm{Cd}, \mathrm{Cs}, \mathrm{Mo}$, Se and $\mathrm{Zn}$. However, $\mathrm{Zn}$ was retained by one patient with short bowel syndrome.

6. The serum concentrations of thirteen ( $\mathrm{Ag}, \mathrm{Br}, \mathrm{Co}, \mathrm{Cs}, \mathrm{Cu}, \mathrm{Fe}, \mathrm{Hg}, \mathrm{Mo}, \mathrm{Rb}, \mathrm{Sc}, \mathrm{Se}, \mathrm{W}$ and $\mathrm{Zn}$ ) of the trace elements were found to have some decrease during the period of total parenteral nutrition, mostly in accordance with the corresponding balance values. Fe, in particular, was found to have the directional change in concentration.

7. The administration of trace elements is recommended in long-term total parenteral nutrition.
\end{abstract}

The number of trace elements known to be essential for both men and animals is increasing (National Research Council, r 974; Nielsen \& Sandstead, I974; Schwarz, 1975). There is a growing interest in the significance of the trace elements in long-term intravenous nutrition. Recently, the first report on copper deficiency in long-term parenteral nutrition was published (Karpel \& Peden, I972). Total parenteral nutrition is defined as provision of all nutrients solely by the parenteral route, and will only be used in that sense. However, some authors (James \& MacMahon, 1970) have found little evidence for the necessity to administer trace elements in total parenteral nutrition; other authors think that the trace elements should be included (Wretlind, 1975). The first time a patient was found to be adequately fed only by intravenous nutrition including fat emulsion (Intralipid) for a sufficiently long period to be significant (more than 7 months, June I967-February 1968), trace elements were given without any adverse effects or any signs of deficiency (Jacobson \& Wretlind, x970; Bergström, Blomstrand \& Jacobson, 1972).

The present study was done to determine the amounts of trace elements supplied

* Present address: Department of Surgery, Huddinge sjukhus, 14I 86 Huddinge, Sweden. 
Table I. Daily infusion schedule for four adult male subjects studied, with special reference to the balance of twenty trace elements, during total parenteral nutrition for $5 d$

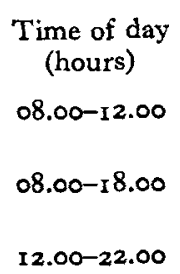

$18.00-22.00$

\section{Infusion}

Carbohydrate solution (150 or $205 \mathrm{~g} / 1$ )"

'Soluble Vitamin Mixture' $\uparrow$

Amino acid solution $\left(\operatorname{Vamin}^{(\mathbf{R})} \uparrow\right)$

Addam Electrolyte Solution§

Fat emulsion (Intralipid\|; $200 \mathrm{~g} / \mathrm{l}$ )

'Lipovit Emulsion for Adults' 9 heparin $(5000 \mathrm{U} / \mathrm{ml})$

Carbohydrate solution $(55,100$ or $150 \mathrm{~g} / \mathrm{l})$
Volume infused (ml)

1000

Io

1000

5

500

2

1000

* 150 g/l: Normodex; Pharmacia Norden AB, Box 159, S-751 04 Uppsala 1, Sweden; 205 g/1: Fruktos-glukos; ACO Läkemedel AB, Box 3026, S-17y $0_{3}$ Solna 3, Sweden.

$\uparrow$ For details, see Table 2.

$\$$ Vitrum AB, Box 12170, S-102 24 Stockholm, Sweden.

$\S$ For details, see Table 3 .

II Vitrum $\mathrm{AB}$.

g For details, see Table 4.

Table 2. Composition (mg) of the lyophilized'Soluble Vitamin Mixture'* containing watersoluble vitamins which was dissolved in $5^{-10} \mathrm{ml}$ of a carbohydrate solution for infusion intravenously during a study of total parenteral nutrition in four adult male subjects

$\begin{array}{lc}\text { Thiamin mononitrate } & \mathrm{I} \cdot 236 \\ \text { Sodium riboflavin phosphate } & 2 \cdot 466 \\ \text { Nicotinamide } & 10 \\ \text { Pyridoxine chloride } & 2.43 \mathrm{I} \\ \text { Folic acid } & 0 \cdot 2 \\ \text { Cyanocobalamin } & 0.002 \\ \text { Sodium pantothenate } & 1 \mathrm{I} \cdot 0 \\ \text { Biotin } & 0 \cdot 3 \\ \text { Sodium ascorbate } & 34 \\ \text { Aminoacetic acid } & 100\end{array}$

* Soluvit, Vitrum AB, Box 121 70, S-102 24 Stockholm, Sweden.

in the infusion schedule used ('the lipid system'; Grotte, Jacobson \& Wretlind, 1976), and the balances of these trace elements in total parenteral nutrition. The preliminary results have been reported previously by Jacobson \& Wester (I973).

\section{EXPERIMENTAL}

\section{Methods}

Four adult male subjects fed only by parenteral nutrition were each studied for a period of $5 \mathrm{~d}$ with special reference to twenty of the trace elements (silver, arsenic, gold, bromine, cadmium, cobalt, chromium, caesium, copper, iron, mercury, lanthanum, molybdenum, rubidium, antimony, scandium, selenium, samarium, tungsten and zinc). During every $5 \mathrm{~d}$ study, total parenteral nutrition was given for $14 \mathrm{~h} / \mathrm{d}$ by gravity-drip according to a special schedule, starting at 08.00 hours (Table I). In the nightly intermissions, the intravenous plastic catheter (Intracath; Bard-Davol) with 
Table 3. Composition (/5 ml sterile water) of 'Addam Electrolyte Solution'* used as a source of additional electrolytes for infusion intravenously during a study of total parenteral nutrition in four adult male subjects

$\begin{array}{lc}\text { Calcium }(\mathrm{mmol}) & 5 \\ \text { Magnesium }(\mathrm{mmol}) & 1 \cdot 5 \\ \text { Iron }(\mu \mathrm{mol}) & 50 \\ \text { Manganese }(\mu \mathrm{mol}) & 40 \\ \text { Zinc }(\mu \mathrm{mol}) & 20 \\ \text { Copper }(\mu \mathrm{mol}) & 5 \\ \text { Fluorine }(\mu \mathrm{mol}) & 50 \\ \text { Iodine }(\mu \mathrm{mol}) & 1 \\ \text { Sorbitol }(\mathrm{g}) & 2 \cdot 5 \\ \text { Chlorine }(\mathrm{mmol}) & 13 \cdot 3\end{array}$

* Vitrum AB, Box г2r70, S-102 24 Stockholm, Sweden; now marketed as Addamel, containing the same amounts of trace elements in ro $\mathrm{ml}$ sterile water.

Table 4. Composition ( $\mathrm{mg} / \mathbf{2} \mathrm{ml}$ sterile water) of 'Lipovit Emulsion for Adults' * containing fat-soluble vitamins for infusion intravenously during a study of total parenteral nutrition in four adult male subjects

$\begin{array}{lc}\text { Retinol (as retinyl palmitate) } & 0.75 \\ \text { Ergocalciferol } & 0.003 \\ \text { Phylloquinone } & 0.15 \\ \text { Soya-bean oil } & 200 \\ \text { Egg-yolk phosphatides } & 24 \\ \text { Glycerol } & 50\end{array}$

* Vitrum AB, Box 12170, S-I02 24 Stockholm, Sweden; now marketed as Vitalipid Adult containing same amount of components in ro ml sterile water.

its end in the superior vena cava was filled at 22.00 hours with $3 \mathrm{ml}$ of a solution of $4 \mathrm{ml}$ heparin $(5000 \mathrm{U} / \mathrm{ml})$ in $16 \mathrm{ml}$ sodium chloride solution $(9 \mathrm{~g} / \mathrm{l})$ and flushed with $2 \mathrm{ml}$ of the diluted solution at 03.00 hours. Additional $\mathrm{NaCl}$ and potassium phosphate (Addex-Natriumklorid and Addex-Kalium) were given in the carbohydrate solutions. Any necessary drugs were given intravenously. The compositions of 'Soluble Vitamin Mixture', 'Addam Electrolyte Solution' and 'Lipovit Emulsion for Adults' are given in Tables 2-4. The daily intravenous supply was: energy 10.2-11.9 MJ (2450$2850 \mathrm{kcal})$, glucose and fructose $300-400 \mathrm{~g}$, amino acids $70 \mathrm{~g}$, fat $106 \mathrm{~g}(6 \mathrm{~g}$ as phosphatides).

During every $5 \mathrm{~d}$ study, $\mathrm{I} \%$ of all parenteral supply, and urine were collected separately and pooled for each subject for later simultaneous determination of the different amounts of the twenty trace elements mentioned previously; for three subjects, faeces were collected and for one patient the gastric suction fluid produced was also collected. Carmine was used as intermittent faecal marker. Also fasting serum samples, taken in the mornings before and after the $5 \mathrm{~d}$ periods of study, were analysed for trace elements. The analyses were done using an ion-exchange technique based on neutron activation and combined with subsequent gamma spectrometry (Wester, Brune \& Samsahl, I964; Wester, 1974). Balance values were calculated as the losses in urine, faeces, and by the nasogastric tube, subtracted from the amount supplied intravenously. 


\section{Subjects}

'The case histories of the four subjects (A, B, C, D) studied were as follows:

Subject $A$. This subject was a 72-year-old man (height I $74 \mathrm{~m}$, body-weight $57 \mathrm{~kg}$ ) in a state of malabsorption after a massive intestinal resection 2 years previously, due to acute occlusion of the superior mesenteric artery. He had only $0.45 \mathrm{~m}$ of the small intestine distal to the ligament of Treitz remaining, anastomosed end-to-end to the middle one-third of the transverse colon (Jacobson, 1972). He was studied from the fourth day of a supporting period of total parenteral nutrition.

Subject $B$. This subject was a 39-year-old man (height $1.74 \mathrm{~m}$, body-weight $68 \mathrm{~kg}$ ) with chronic pancreatitis. He suffered from several acute exacerbations ending with the development of a pancreatic cyst treated by marsupialization to the stomach. During one of the preceding exacerbations of pancreatitis he was treated by total parenteral nutrition first for I week and, after a period of I week without treatment, for a further 2 weeks. The $5 \mathrm{~d}$ balance study of trace elements was begun from the seventh day of this second period of total patenteral nutrition for $\mathrm{r} 4 \mathrm{~d}$, when his abdominal symptoms had disappeared and he was in a relatively steady state.

Subject $C$. This subject was also a 72-year-old man (approximate height $\mathrm{I} \cdot 70 \mathrm{~m}$, body-weight $75 \mathrm{~kg}$ ), who I year previously had had gastrointestinal bleeding. After a period of 9 months, gastric X-ray was done which showed an ulceration. A few months later, a gastric resection was done according to the Billroth $I$ procedure. At the same time a hepatic cirrhosis was also found, and verified by biopsy. On the tenth day postoperatively, there were signs of a suture insufficiency which led to a gastrocutaneous fistula. Total parenteral nutrition was then begun and continued for more than I month. Towards the end of this intravenous regimen, the $5 \mathrm{~d}$ balance study of trace elements was made about 6 weeks after the operation.

Subject $D$. This subject was a 66 -year-old man (approximate height $\mathrm{I} \cdot 85 \mathrm{~m}$, bodyweight $68 \mathrm{~kg}$ ) with an acute gastric retention. After drainage of a somewhat dilated ventricle, $\mathrm{X}$-ray was done which showed a malignant deformation of the bulbus duodeni. As he had lost a few kilogrammes in body-weight in the preceding month because of the inability to eat adequately, he was preoperatively given total parenteral nutrition for 2 weeks. The $5 \mathrm{~d}$ balance study was started after $8 \mathrm{~d}$ of total parenteral nutrition. The operation showed a poorly differentiated gastric carcinoma with metastases to the lymph glands, but none in the liver. Faeces were not collected.

\section{RESULTS}

The administered amounts were found to be higher than the intended administered amounts for $\mathrm{Zn}$ and a little lower for $\mathrm{Cu}$ and $\mathrm{Fe}$ (Table 5). The range of amounts of $\mathrm{Br}, \mathrm{Cr}, \mathrm{Rb}$ and $\mathrm{W}$ administered were wide, but for the other trace elements the amounts were rather similar for the four subjects.

The balance calculations indicated a substantial average retention of $\mathrm{Fe}$ of $2.3 \mathrm{mg}$, $\mathrm{Sb}$ was also retained by all patients. An average retention was found for $\mathrm{Ag}, \mathrm{Co}, \mathrm{Cr}$, $\mathrm{Sc}$ and W. However, subjects $\mathrm{C}$ and $\mathrm{D}$ had a urinary excretion of Co of $7 \cdot \mathrm{I}$ and $5.2 \mu \mathrm{g} / 24 \mathrm{~h}$, respectively, which slightly exceeded the value obtained by analysis for 
the amount given. Amounts of urinary $\mathrm{Cr}, \mathrm{Cu}$ and $\mathrm{Sc}$ were less than those administered for all subjects, whereas the amount of urinary $W$ for one subject, subject $B$, was slightly higher than the amount administered (Table 5).

Negative balances were found for $\mathrm{Br}, \mathrm{Cs}, \mathrm{Mo}, \mathrm{Rb}$ and $\mathrm{Se}$ for all subjects. The urinary excretion of $\mathrm{Cs}, \mathrm{Rb}$ and $\mathrm{Se}$ was higher than the amount administered for all subjects.

One subject, subject $\mathrm{C}$, had a mean daily urinary excretion of $\mathrm{Br}$ of only $120 \mu \mathrm{g}$. which was less than the analysed value for the amount administered (210 $\mu \mathrm{g}$ ). The urinary excretion of Mo approximately corresponded to the amount administered for three subjects, although subject $B$ had a higher average urinary excretion $(35 \mu \mathrm{g} / \mathrm{d})$, which was greater than the analysed value for the amount administered $(8.6 \mu \mathrm{g})$. $\mathrm{Br}$ and $\mathrm{Rb}$ were generally lost in large quantities (Table 5).

Three subjects had mean negative balances of $\mathrm{As}, \mathrm{Au}, \mathrm{Cd}$ and $\mathrm{Zn}$, and two subjects had a negative balance of $\mathrm{Hg}$ (Table 5). For subject $\mathrm{B}$, the amount of As administered was not determined, but his mean urinary excretion of As, $16 \mu \mathrm{g} / \mathrm{d}$, exceeded the amount administered for all the other subjects, whose urinary excretions of As were greater than the administered amounts throughout the study. Three subjects had urinary excretions of $\mathrm{Au}$ and $\mathrm{Cd}$ which were higher than the amount administered. Subject A, however, had a daily urinary excretion of $\mathrm{I}^{\circ} 5 \mu \mathrm{g} \mathrm{Cd}$ of $\mathrm{I} \cdot 7 \mu \mathrm{g} \mathrm{Cd}$ administered and subject D's urinary excretion of Au was $2 \cdot 1 \mathrm{ng}$ of $5.4 \mathrm{ng} \mathrm{Au}$ administered. Only subject $A$ had a urinary excretion of $\mathrm{Zn}$ which was less than the amount administered, 0.69 and $\mathrm{I} .67 \mathrm{mg}$ respectively. Urinary $\mathrm{Hg}$ was only determined for subjects $C$ and $D$.

The average negative balances of $\mathrm{Cu}$ and $\mathrm{Zn}$ depended mostly on the large losses by gastric suction and in urine respectively: values for both these elements were obtained for subject $\mathrm{C}$ who had liver cirrhosis. If the nasogastric tube losses were excluded, and assuming that subject $\mathrm{D}$ had a faecal $\mathrm{Cu}$ loss similar to the other three subjects, all subjects would have substantially retained $\mathrm{Cu}$. $\mathrm{Zn}$, however, was only retained by subject A with malabsorption.

The faecal losses were generally much lower than the analysed amounts administered for the trace elements studied (Table 5).

Only $\mathrm{Rb}$ was found to be lost in the faeces in amounts exceeding those administered, for all subjects studied; faecal Rb was not determined for subject $D$.

The serum concentrations of $\mathrm{Hg}$ and $\mathrm{Rb}$ were found to decrease in all subjects during the $5 \mathrm{~d}$ study of total parenteral nutrition. In three subjects serum $\mathrm{Ag}, \mathrm{Br}, \mathrm{Co}$, $\mathrm{Mo}$, Se and $\mathrm{W}$ were found to decrease, whereas serum $\mathrm{Cu}, \mathrm{Fe}$ and Sc only decreased in two subjects during the period of study, although the mean values indicated a decrease (Table 5). A mean increase in the serum concentrations was found for As, $\mathrm{Cr}$ and $\mathrm{Sb}$, but individually, an increase in each of these trace elements was only found in two subjects.

The direction of the serum deviations was mostly in accordance with the corresponding balance values, with the exception of $\mathrm{Fe}$.

No adverse clinical effects of any kind were observed during the total parenteral nutrition with administration of the trace element solution. 


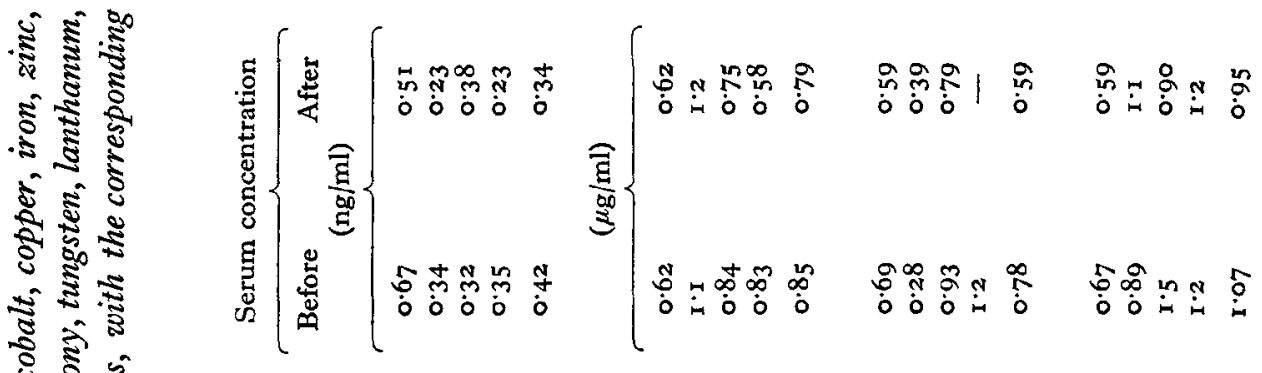

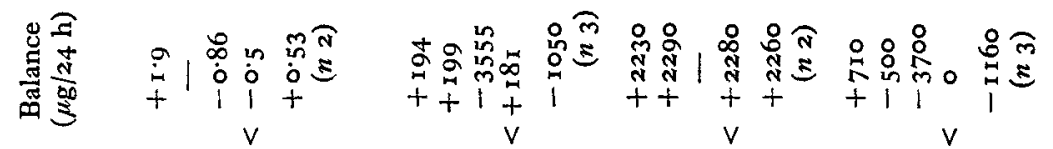

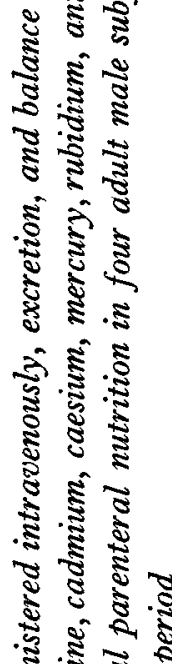

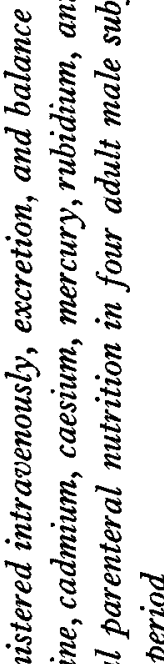

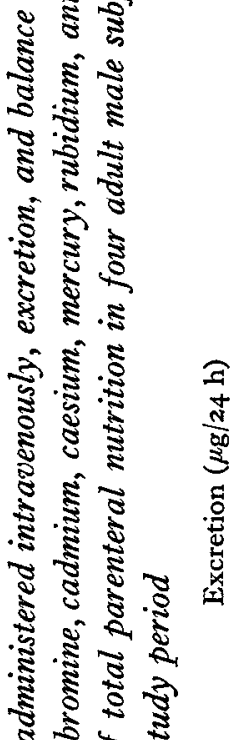

.

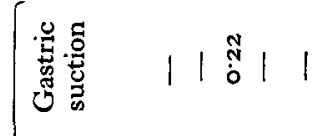

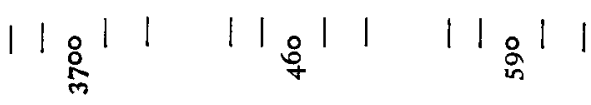

兽

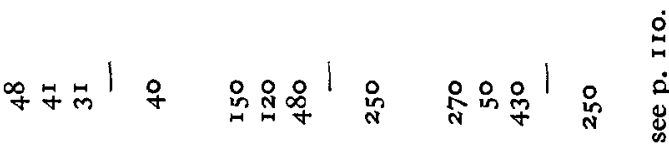

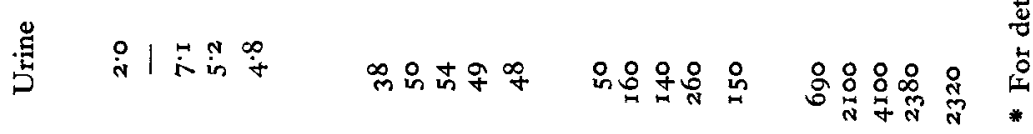

造 is

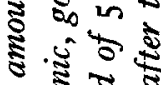

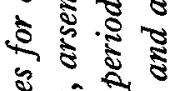

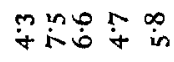

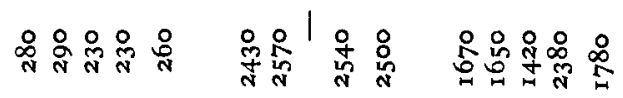

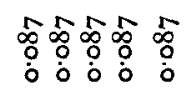

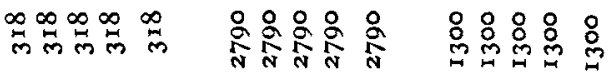

芣

8

3

里

도 


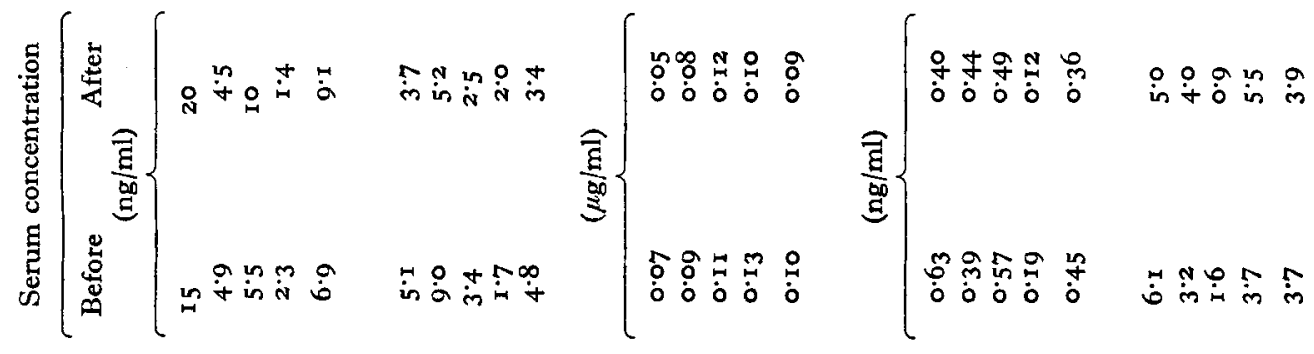

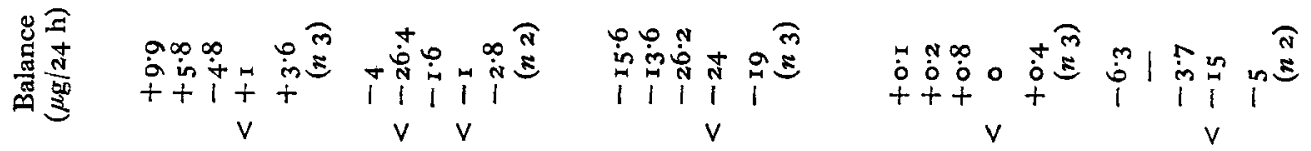

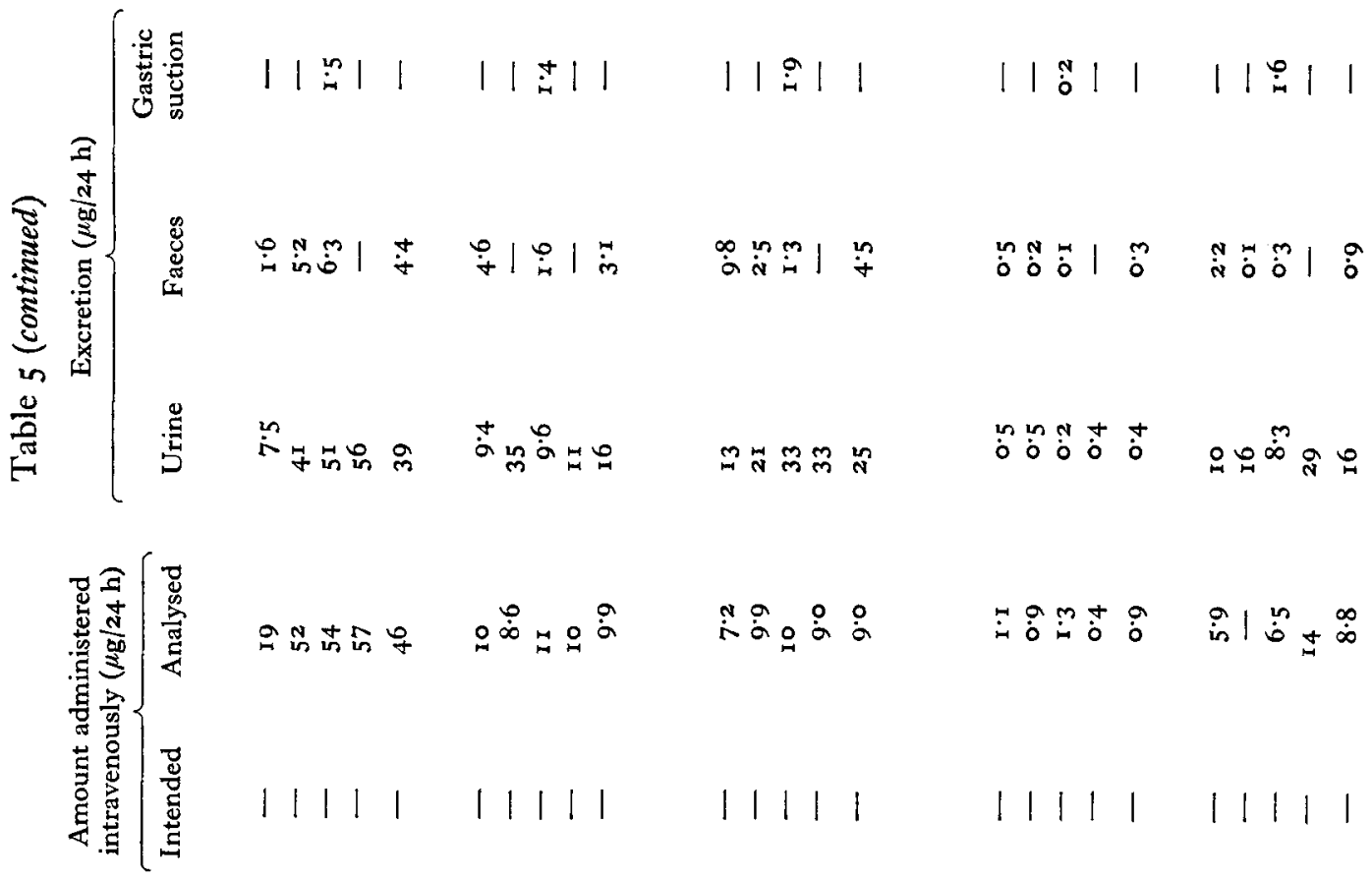

苕

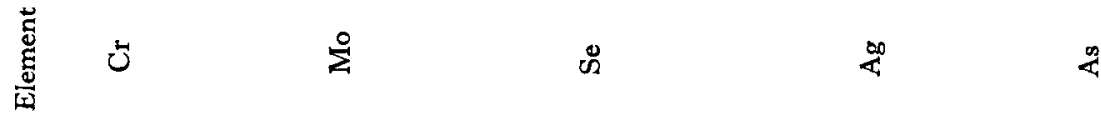




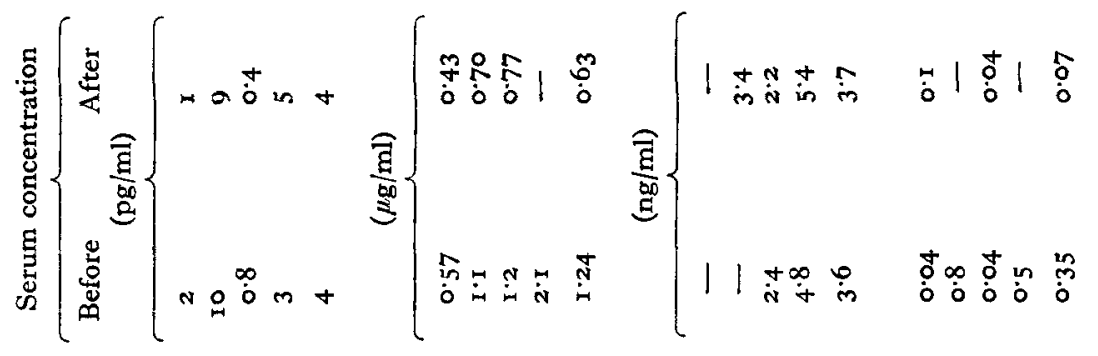

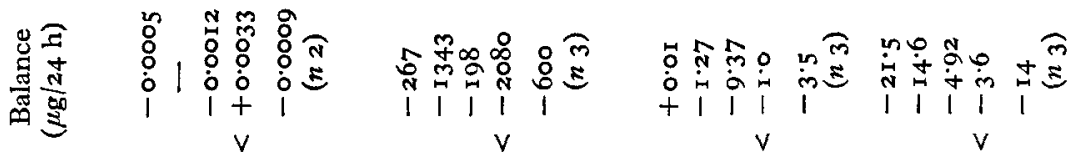

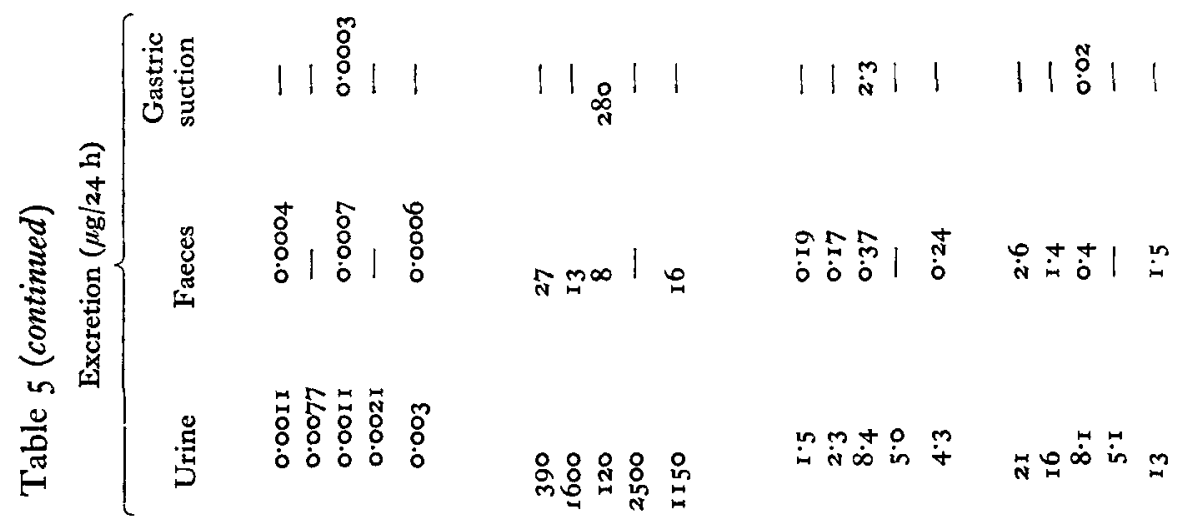

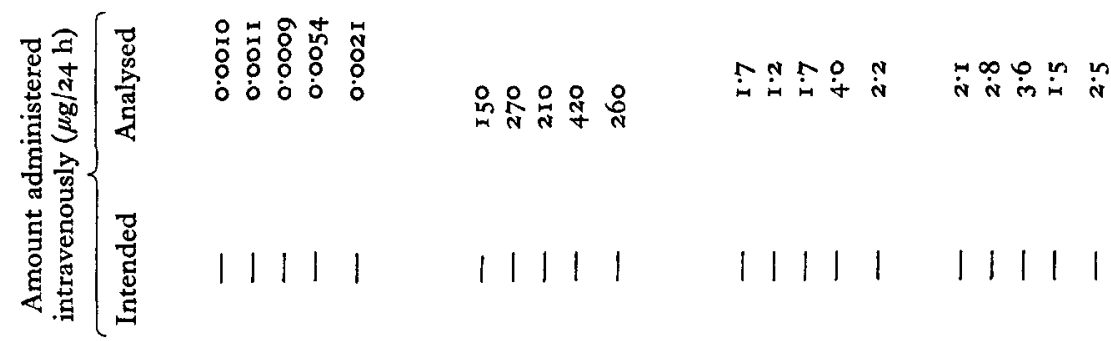
总

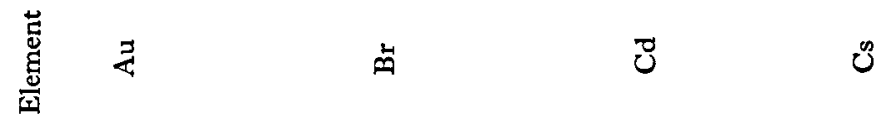


Vol. 37

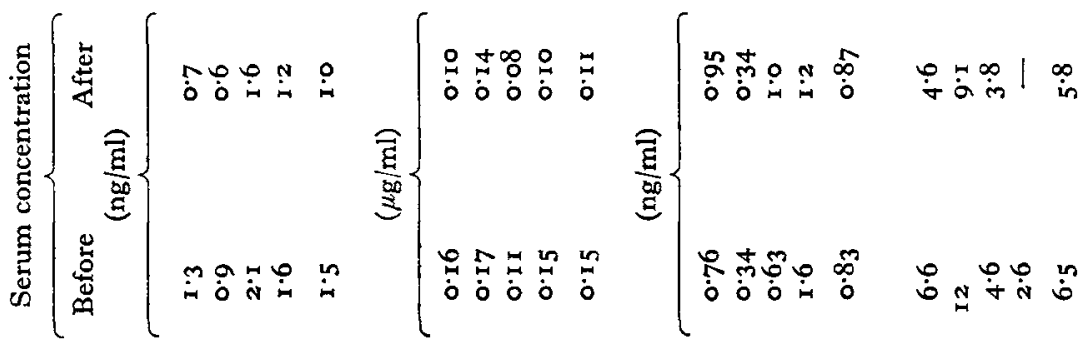

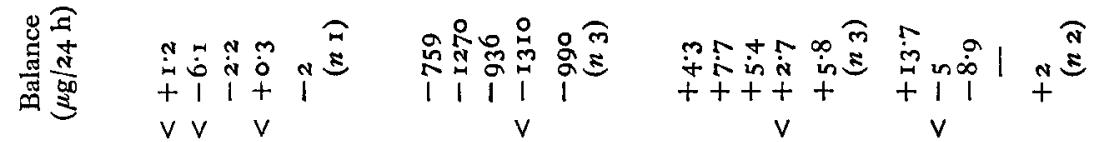

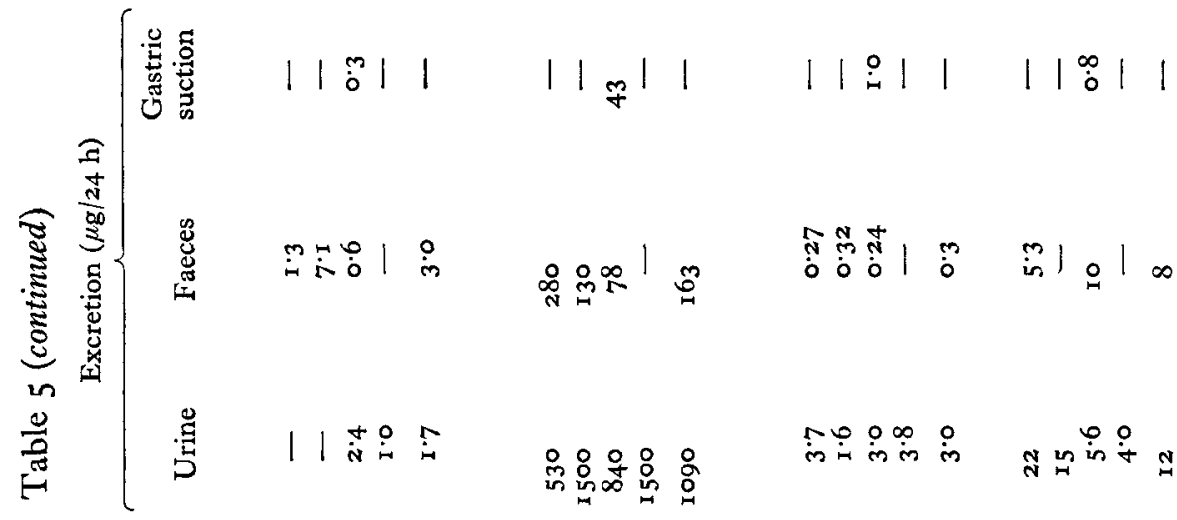

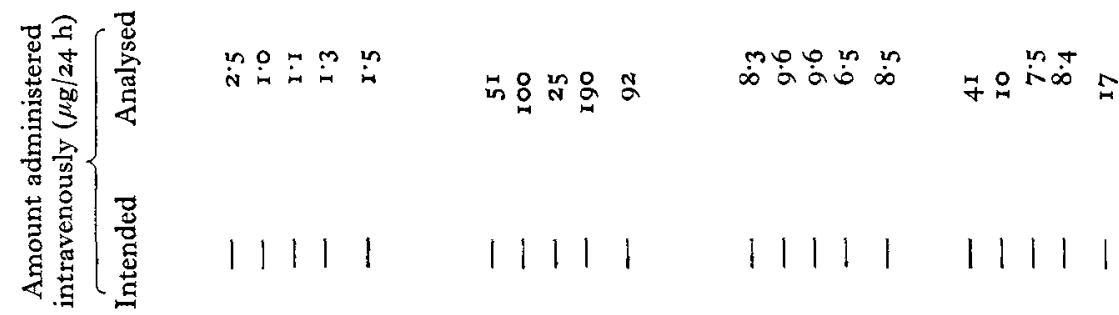

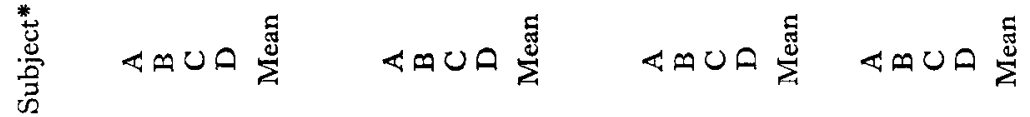

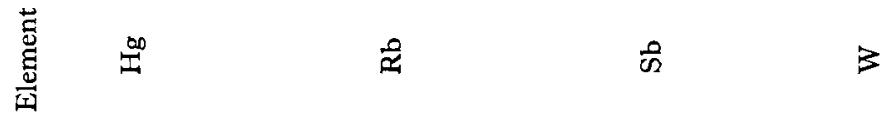




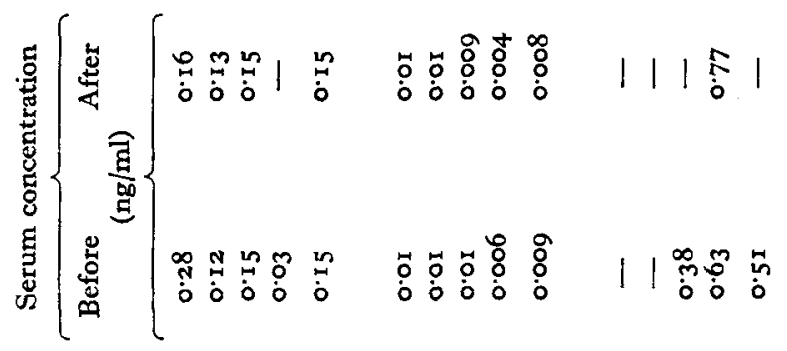

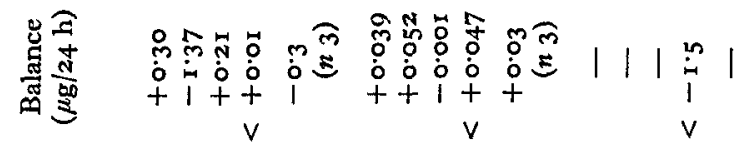

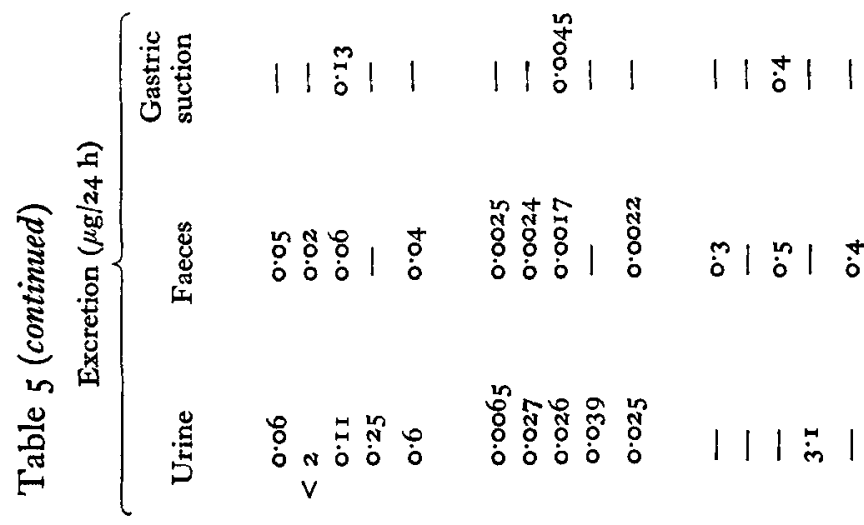

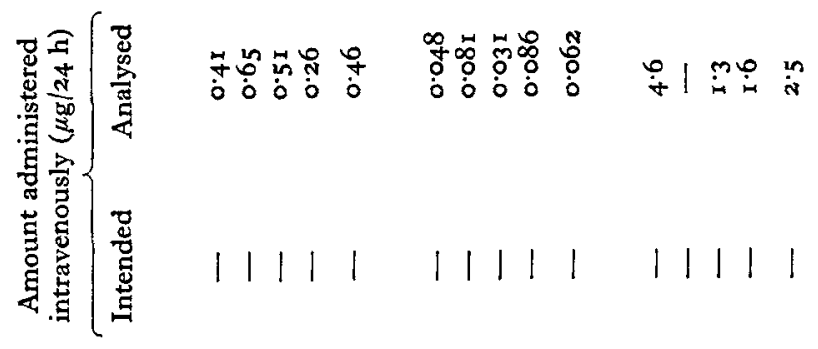

㞭

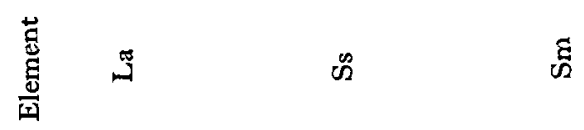




\section{DISCUSSION}

A suitable infusion schedule for long-term total intravenous nutrition was chosen for patients in steady-state without particularly increased losses of any kind. A relatively short infusion time in $24 \mathrm{~h}$ was preferred so the veins were not strained (McNair \& Dudley, 1959; Grotte et al. 1976; Jacobson \& Wretlind, 1976). However, the subject with cirrhosis, who was undergoing gastric suction, had losses of probably both gastric and pancreatic juice and bile, as he was operated on according to the Billroth I procedure.

\section{Trace elements established as essential for man and animals}

Co. Co has been known since $\mathrm{r} 935$ as a dietary essential (Underwood \& Filmer, 1935). In hypertensive subjects before treatment only $0.73 \pm 0.48 \mu \mathrm{g} \mathrm{Co} / 24 \mathrm{~h}$ urine sample was found (Wester, 1973), and in normal subjects $0.2-1 \cdot 0 \mu \mathrm{g} \mathrm{Co} / 24 \mathrm{~h}$ urine

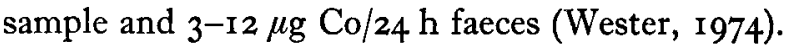

In the parenteral study reported, the excretion of Co in the urine in $24 \mathrm{~h}$ was higher than that of the hypertensive subjects, whereas the faecal Co excretion was much lower. The serum levels reported were within the normal range: $0.52 \pm 0.43 \mathrm{ng} / \mathrm{ml}$, determined in healthy subjects (Wester, I973).

$\mathrm{Cu}$. $\mathrm{Cu}$ has long since been established as essential for the utilization of $\mathrm{Fe}$ in haemoglobin formation in higher animals (Hart, Steenbock, Waddell \& Elvehjem, 1928). Minimum $\mathrm{Cu}$ requirements have been assessed at $0.4 \mathrm{mg}$ elemental $\mathrm{Cu} / \mathrm{d}$, equivalent to $\mathrm{I} \cdot 6 \mathrm{mg} \mathrm{Cu}$ sulphate administered intravenously for maintenance therapy in a woman on indefinite parenteral nutrition due to short bowel syndrome after massive intestinal resection (Dunlap, James \& Hume, I 974).

In human plasma $93 \%$ of the $\mathrm{Cu}$ is bound to caeruloplasmin and $7 \%$ to albumin (Sandstead, Burk, Booth \& Darby, 1970). Normal serum Cu, according to Wester ( 1973 ) is $\mathrm{I} \cdot \mathrm{OI} \pm 0.33 \mu \mathrm{g} / \mathrm{ml}$; the mean level found in the present study was similar to this value. In severe $\mathrm{Cu}$ deficiency, with neutropenia and anaemia, a serum $\mathrm{Cu}$ level as low as $\mathrm{I}$ ro $\mu \mathrm{g} / 1$, with a parallel serum caeruloplasmin concentration of $90 \mathrm{mg} / \mathrm{l}$ (normal 100-400 mg/l) has been reported (Dunlap et al. 1974). This was, however, during parenteral nutrition without essential fatty acids. In the present study, the essential fatty acids were given in the fat emulsion Intralipid (Jacobson \& Wretlind, 1976). This might be of importance, as recent studies suggest that low intakes of $\mathrm{Cu}$ promote an increase in serum cholesterol, indicating a relationship between $\mathrm{Cu}$ and lipid metabolism (FAO/WHO, I973).

$F e$. The Fe content of the normal adult man is estimated to be $4-5 \mathrm{~g}$; most of it bound in complex forms to protein, either as porphyrin or haem compounds, particularly haemoglobin and myoglobin, or as non-haem protein-bound compounds such as ferritin and transferrin. In certain diseases very large amounts of $\mathrm{Fe}$ may also be present as haemosiderin (Underwood, 197I). The concentration of plasma ferritin reflects the level of body Fe stores (Jacobs, Miller, Worwood, Beamish \& Wardrop, 1972).

Faecal excretory Fe has been estimated at about $0.2 \mathrm{mg} / \mathrm{d}$ in young women, by 
chemical balance studies (Ingalls \& Johnston, I954), and at $0.3-0.5 \mathrm{mg} / \mathrm{d}$ for normal subjects, by a radioactive tracer technique (Dubach, Moore \& Callender, 1955). This $\mathrm{Fe}$ is derived from desquamated cells and from the bile. The amount of $\mathrm{Fe}$ eliminated in the urine varies from as low as $0.02 \mathrm{mg} / \mathrm{d}$ (Wester, 1974) to as high as $2.7 \mathrm{mg} / \mathrm{d}$ (Wester, 1971), whereas the mean urinary excretion of Fe by normal adult males and females is estimated to be $0.25 \mathrm{mg} / \mathrm{d}$ (Hawkins, 1964).

In surgical patients, with Fe deficiency, but without particular anaemia, a general administration of an $\mathrm{Fe}$-dextran complex for intravenous use, has been advocated. In anaemia, approximately $25^{\circ} \mathrm{mg} \mathrm{Fe}$-dextran may be given as a single dose for each gram of haemoglobin concentration below normal, expressed in $\mathrm{g} / \mathrm{roo} \mathrm{ml}$ blood (Saferin \& Winne, 1975).

The Fe of the plasma is completely bound to transferrin, a $\beta_{1}$-globulin, usually $30-40 \%$ saturated (Holmberg \& Laurell, 1947). By neutron activation analysis serum concentrations of $\mathrm{I} \cdot 2 \mathrm{I} \pm 0.78 \mu \mathrm{g} \mathrm{Fe} / \mathrm{ml}$ were found in normal subjects (Wester, 1973).

$Z n$. Not until 1934, was indisputable evidence obtained that $Z n$ is a dietary essential for the rat (Todd, Elvehjem \& Hart, 1934).

In human nutrition, $\mathrm{Zn}$ has recently been related to the occurrence of dwarfism and hypogonadism in boys in parts of the Middle East (Prasad, 1966), to wound healing (Pories \& Strain, 1966), improved taste acuity (Henkin, Schechter, Hoye \& Mattern, 1971), and acrodermatitis enteropathica (Barnes \& Moynahan, 1973), although as early as I939 Keilin \& Mann (1939) showed that $\mathrm{Zn}$ is a constituent of the enzyme carbonic anhydrase $(E C$ 4.2.1.r). However, in wound healing $\mathrm{Zn}$ is required only in $\mathrm{Zn}$-deficient states (Henkin, 1974). In animals, evidence has linked $\mathrm{Zn}$ as a trace element essential to the proper mobilization of retinol from the liver (Smith, McDaniel, Fan \& Halsted, 1973).

Ingestion of $600 \mathrm{mg}$ zinc sulphate daily to promote wound healing is considered safe (Louria, Joselow \& Browder, 1972 ), but a larger $\mathrm{Zn}$ intake causing $\mathrm{Zn}$ intoxication can produce either lung or intestinal tract disturbances or lethargy (Murphy, 1970).

Healthy humans excrete $0.2-0.8 \mathrm{mg} \mathrm{Zn/d}$ in the urine (mean $0.5 \mathrm{mg} \mathrm{Zn} / \mathrm{d}$ ) (Walker, Dawson, Kelleher \& Losowsky, 1973) on normal ingestion of $10-15 \mathrm{mg} \mathrm{Zn/d}$ without any appreciable variation related to the level of $\mathrm{Zn}$ in the diet, and not significantly increased following $\mathrm{Zn}$ injections (Underwood, 1971). In cryptogenic hepatic cirrhosis, but not in malabsorption, the urinary excretion of $\mathrm{Zn}, 0.7 \mathrm{mg} / 24 \mathrm{~h}$, is well above normal (Walker et al. 1973). Six patients with albuminuria averaged 2.I $\mathrm{mg}$ $\mathrm{Zn} / \mathrm{d}$ in their urine (range $1 \cdot 0-3.8 \mathrm{mg} \mathrm{Zn} / \mathrm{d}$ ) (McCance \& Widdowson, I942), whereas postalcoholic cirrhotics excreted from $\mathrm{I} \mathrm{mg} \mathrm{Zn} / \mathrm{d}$ in their urine (Vallee, Wacker, Bartholomay \& Hoch, 1957). Increased urinary excretion of $\mathrm{Zn}$ occurs in total starvation in man, reaching levels of $5^{-6} \mathrm{mg} \mathrm{Zn/d} \mathrm{(Spencer} \mathrm{\&} \mathrm{Samachson,} \mathrm{1970).}$ Different mechanisms may account for the low serum $\mathrm{Zn}$ and high urinary $\mathrm{Zn}$, as in alcoholic liver disease an increased renal clearance of $\mathrm{Zn}$ was found regardless of the serum level (Sullivan \& Heaney, I970).

Increased urinary $\mathrm{Zn}$ losses have been found during total parenteral nutrition. Heat sterilization of both protein hydrolysates and crystalline amino acids with carbohydrates, result in the formation of sugar-amine compounds $(3-6 \%)$ (Christensen, 
Wilber, Coyne \& Fisher, 1955; Freeman, Stegink, Meyer, Fry \& den Besten, 1975). These compounds are mostly excreted in the urine during intravenous nutrition with the heat-sterilized (autoclaved) solutions in association with a fourfold increase in urinary $\mathrm{Zn}$, up to $4.5 \mathrm{mg} / \mathrm{d}$ (Freeman et al. 1975). The explanation was thought to be that $\mathrm{Zn}$ was chelated to the sugar-amino compound, since amino acid binding of $\mathrm{Zn}$ was not a factor, such as simultaneous increase in both urinary $\mathrm{Zn}$ and histidine, which can occur after a histidine load with excessive plasma histidine levels (Prasad \& Oberleas, 1970). However, the amino acid solution used in the study reported, Vamin, contains $100 \mathrm{~g}$ fructose $/ 1$. It is sterilized by microfiltration and mild varm treatment, which does not give rise to any appreciable amount of sugar-amino compounds (I. Håkansson, personal communication).

The dietary requirement of $\mathrm{Zn}$ for children and young women has been estimated to be $6 \mathrm{mg} / \mathrm{d}$ (Tribble \& Scoular, 1954; Engel, Miller \& Price, I966), whereas adults have a slightly higher dietary requirement (Halsted, Smith \& Irwin, 1974). In the present parenteral study only I. $8 \mathrm{mg} \mathrm{Zn} / \mathrm{d}$ was given, with a resulting mean negative balance. The only subject who retained $\mathrm{Zn}$ was subject $\mathrm{A}$, with a short bowel, but even his urinary excretion was twice that in the faeces. The low faecal $\mathrm{Zn}$ excretion of subject $\mathrm{B}$ may be explained by his chronic pancreatitis, with probably only a small production of pancreatic juice, but the large urinary excretions of subjects $B$ and $D, 2 \cdot I$ and $2.4 \mathrm{mg} \mathrm{Zn} / \mathrm{d}$ respectively, are difficult to explain, although occasionally a high urinary excretion of $\mathrm{Zn}$ has been reported in patients with pancreatic insufficiency (Wester, 1971). The urinary excretion of $4^{\cdot} \cdot \mathrm{Img} \mathrm{Zn} / \mathrm{d}$ in subject $\mathrm{C}$ with postalcoholic cirrhosis is more consonant with the earlier reported findings. Although sugar-amino compounds have not been found in the amino acid solution used, their presence would explain the high urinary $\mathrm{Zn}$ excretion in the total parenteral nutrition studied.

In plasma about one-third of the $\mathrm{Zn}$ is loosely associated with the serum albumins, and the remainder is more firmly bound to the globulins, particularly the $\alpha_{1}$-globulin fraction (Wolff, 1956; Sandstead et al. 1970; Walker et al. 1973). The Zn content of serum is consistently higher than that of plasma; on average $16 \%$ higher (Foley, Johnson, Hackley, Smith \& Halsted, 1968). Fasting plasma Zn concentrations have been reported to be significantly lower in patients with cryptogenic cirrhosis $(0.7 \mathrm{I}$ $\mu \mathrm{g} / \mathrm{ml})$ and malabsorption $(0 \cdot 76 \mu \mathrm{g} / \mathrm{ml})$ than in controls $(0 \cdot 97 \mu \mathrm{g} / \mathrm{ml})$ (Walker $e t$ al. 1973). The serum content of healthy subjects has been estimated to be $0.95 \pm 0.44 \mu \mathrm{g}$ $\mathrm{Zn} / \mathrm{ml}$ (Wester, I973).

In the present parenteral study the mean serum $\mathrm{Zn}$ level was normal. In subject $\mathrm{A}$, however, with a short bowel syndrome, low serum values were found which might be correlated both with his atherosclerosis (Volkov, 1963 ), and with malabsorption, with a tendency to develop pernicious anaemia (Vallee \& Gibson, 1949). In subject C, who had cirrhosis, the serum $\mathrm{Zn}$ was normal, although $\mathrm{Zn}$ balance was substantially negative.

\section{Trace elements known to be essential to animals}

$\mathrm{Cr}$. Trivalent $\mathrm{Cr}$ is an essential trace element, and has recently been established as a cofactor with insulin, necessary for normal glucose utilization (Mertz, 1969). Man's 
requirement of dietary $\mathrm{Cr}$ is proportionally influenced by the amounts of refined carbohydrates in the intake. An institutional diet was found to provide about $80 \mu \mathrm{g}$ $\mathrm{Cr} / \mathrm{d}$ (Schroeder, Balassa \& Tipton, I962), whereas by neutron activation analysis an ordinary hospital diet has been found to provide $16-67 \mu \mathrm{g} \mathrm{Cr} / \mathrm{d}$ (Boström \& Wester, 1968; Wester, 1974). These values are within the same range as those found in the present study. Injected $\mathrm{Cr}$ in the rat is excreted mainly in the urine with small amounts lost in the bile and small intestine (Hopkins, 1965). Urinary $\mathrm{Cr}$ has been found to vary between 2 and $27 \mu \mathrm{g} / 24 \mathrm{~h}$, being lower than the intake on every occasion (Boström \& Wester, 1968; Wester, 1974). In healthy women a narrow range of 6-10 $\mu \mathrm{g} \mathrm{Cr} / \mathrm{d}$ in the urine has been reported (Mitman, Wolf, Kelsay \& Prather, I975). In some subjects a substantial $\mathrm{Cr}$ retention has been found (Boström \& Wester, r 968 ). In the present study the urinary excretion accounted for a large proportion of the $\mathrm{Cr}$ losses resulting in a small mean retention.

$\mathrm{Cr}$ disappears from the blood quite rapidly after injection and the concentration in blood is not in equilibrium with the tissue stores (FAO/WHO, 1973). Consequently, blood is a poor indicator of the $\mathrm{Cr}$ status. $\mathrm{Cr}$ supplements of $\mathrm{I} 50 \mu \mathrm{g} / \mathrm{d}$ administered to older subjects have resulted in a restoration to normal of the serum $\mathrm{Cr}$ increment response (FAO/WHO, 1973).

Mo. Mo is essential in animal nutrition, first suggested in 1953 with the discovery that flavoprotein enzyme, xanthine oxidase $(E C$ I .2.3.2) is a Mo-containing metalloenzyme which is dependent for its activity on the presence of this metal (de Renzo, Kaleita, Heytler, Oleson, Hutchings \& Williams, r953 $a, b$; Richert \& Westerfeld, 1953). However, there is no evidence to suggest that any clinical syndrome in man is directly attributable to a deficiency of $\mathrm{Mo}$ (FAO/WHO, 1973). In the urine of schoolchildren a mean Mo concentration of $33 \mu \mathrm{g} / 1$ has been found (FAO/WHO, 1973), whereas by the neutron activation technique a urinary excretion range of $25-250 \mu \mathrm{g} / 24 \mathrm{~h}$ has been reported for adults (Boström \& Wester, I968; Wester, 1973, 1974).

The dietary intake of Mo varies widely. An ordinary hospital diet provides between 44-1000 $\mu \mathrm{g} \mathrm{Mo/d} \mathrm{(Tipton,} \mathrm{Stewart} \mathrm{\&} \mathrm{Martin,} \mathrm{I966;} \mathrm{Boström} \mathrm{\&} \mathrm{Wester,} \mathrm{I968;}$ Wester, 1971, 1974). This resulted in both positive and negative balances, and as high a faecal Mo excretion as $1100 \mu \mathrm{g} / \mathrm{d}$ has been reported (Wester, 197I).

Allaway, Kubota, Losee \& Roth (1968) found that more than $80 \%$ of whole blood samples contained less than $5 \mathrm{ng} \mathrm{Mo} / \mathrm{ml}$, and only about $3 \%$ contained more than I $00 \mathrm{ng} \mathrm{Mo} / \mathrm{ml}$, whereas Wester (1973) found $5 \cdot 6 \pm 2 \cdot \mathrm{I} \mathrm{ng} \mathrm{Mo} / \mathrm{ml}$ serum.

$S e$. Discovered in 1817 by Berzelius, Se is widely used in pigment, electronics, glass, ceramics, and the steel industries (Louria et al. 1972). The essentiality of Se for chicks, with a role beyond that of a substitute for a normal intake of vitamin $\mathrm{E}$, has recently been established (Thompson \& Scott, 1969, I970), but neither Se deficiency nor Se poisoning has been clearly established in human populations (Burk, Pearson, Wood \& Viteri, 1967).

Se deposition in the tissues is highly labile. The results of studies on rats and lambs have indicated that, after injections of stable or radioactive Se, the retained Se is lost from the tissues, at first rapidly and then more slowly. It is excreted in the faeces, the 
urine and the expired air (Blincoe, 1960; Yousef, Coffman \& Johnson, 1968; Lopez, Preston \& Pfander, 1969).

The main pathway of excretion of Se is the urine, but this is influenced by sulphate. Thus, the urinary excretion of Se, after an intraperitoneal dose of sodium selenate, was increased nearly threefold in rats given increased amounts of sulphate parenterally, or in the diet (Ganther \& Baumann, 1962).

An ordinary hospital diet provides $23^{-200} \mu \mathrm{g}$ Se/d (Boström \& Wester, I968; Wester, 1971, 1974).

\section{Trace elements not established as essential for man or animals}

$\mathrm{Ag}$. Ag has only occasionally been determined in the balance studies of trace elements. In an ordinary hospital diet $\mathrm{I} \cdot 4-\mathrm{I} 6 \mu \mathrm{g} \mathrm{Ag} / \mathrm{d}$ were supplied (Wester, $197 \mathrm{I}$ ). This is more than the parenteral supply found for all subjects. In a balance study of two subjects with pancreatic insufficiency $0.82-\mathrm{I} \cdot 0 \mu \mathrm{g} \mathrm{Ag} / 24 \mathrm{~h}$ was found in the urine (Wester, 1971). This is also more than the values found in the parenteral study.

The normal concentration of $\mathrm{Ag}$ in serum has been reported to be $0.9 \pm 0.4 \mathrm{ng} / \mathrm{ml}$ (Wester, 1973). In the parenteral study, only the subject with gastric carcinoma (D) had serum values clearly below this range.

As. As is widely distributed in the biosphere, both in the air and in the water. A normal hospital diet has been found to supply both a low range of 8.4-66 $\mu \mathrm{g}$ As/d (Boström \& Wester, 1968) and a wide range of 40-1400 $\mu \mathrm{g} \mathrm{As} / \mathrm{d}$ (Wester, 1971, 1974). Using neutron activation analysis, a mean value of $0.004 \mu \mathrm{g} \mathrm{As} / \mathrm{g}$ whole blood has been reported (Brune, Samsahl \& Wester, 1966), which is somewhat higher than the levels found in this study.

$A u$. Au, like Ag, is only occasionally determined in balance studies of trace elements. In an ordinary hospital diet 4-30 ng Au/d were supplied (Wester, I974) (40-220 ng $\mathrm{Au} / \mathrm{d}$, Boström, \& Wester I968). This intake greatly exceeds the parenteral administration for all but one of the subjects studied.

In serum, Au concentrations from $2-20 \mathrm{pg} / \mathrm{ml}$ have been reported (Wester, $197 \mathrm{I}$ ). All the serum values of the present parenteral study were within the same range.

$\mathrm{Br} . \mathrm{Br}$ is present in the ordinary hospital diet in large amounts. Daily $\mathrm{Br}$ intakes of $3.9-6.8 \mathrm{mg}$ and $0.6-4.8 \mathrm{mg}$ have been reported (Wester, 1971, 1974), sometimes resulting in substantially positive $\mathrm{Br}$ balances. Consequently, in the reported study the low supply resulted in a negative balance mainly attributable to the high urinary excretion rate.

By neutron activation analysis, a mean whole blood concentration of $2 \cdot 75 \mu \mathrm{g} \mathrm{Br} / \mathrm{g}$ has been found (Bowen, 1959), and in serum $3.7 \pm 1.5 \mu \mathrm{g} \mathrm{Br} / \mathrm{ml}$ (Wester, 1973), which is slightly higher than the values obtained in the parenteral study reported on here.

$C d$. Cd has not been attributed any special role in the living cell (Underwood, I 97 $\mathrm{x}$ ), but increased exposure to $\mathrm{Cd}$ produces a characteristic clinical picture (Louria et al. 1972). The metabolism of $\mathrm{Cd}$ is known to be greatly affected by the relative intakes of $\mathrm{Zn}, \mathrm{Cu}$ and other metals and, vice versa (Underwood, 1971; FAO/WHO, I973; Schroeder \& Nason, 1974). The average intake is between 50 and $60 \mu \mathrm{g} \mathrm{Cd} / \mathrm{d}$ 
(Friberg, Piscator, Nordberg \& Kjellström, 1974), whereas the ordinary hospital diet supplies 5-68 $\mu \mathrm{g} \mathrm{Cd} / \mathrm{d}$ (Boström \& Wester, 1968; Wester, r971, r974), which is much higher than the parenteral administration in this report.

Normal urine varies in $\mathrm{Cd}$ content. An average of $10-13 \mu \mathrm{g} \mathrm{Cd} / 1$ urine has been reported (Smith \& Kench, 1957; Perry \& Perry, 1959), whereas by neutron activation technique only $\mathrm{I}-\mathrm{I} 2 \mu \mathrm{g} \mathrm{Cd} / \mathrm{d}$ were found in the urine (Boström \& Wester, 1968 ; Friberg et al. 1974; Wester, 1971, 1974). Consequently, the mean urinary excretion of $4 \mu \mathrm{g} / 24 \mathrm{~h}$, obtained in the present parenteral study, was entirely within this range.

The average negative balance found is consonant with the rather low serum levels reported. The $\mathrm{Cd}$ concentration in normal human blood is low, but varies widely. Imbus, Cholak, Miller \& Sterling (1963) have reported a range of $3-54 \mathrm{ng} \mathrm{Cd} / \mathrm{ml}$ whole blood, with a median concentration of $7 \mathrm{ng} / \mathrm{ml}$, whereas Kubota, Lazar \& Losee (1968) found a median concentration of $18 \mathrm{ng} \mathrm{Cd} / \mathrm{ml}$. In serum, Wester (1973) found $2 \cdot 5 \pm \mathrm{I} \cdot 7 \mathrm{ng} \mathrm{Cd} / \mathrm{ml}$, which is quite consistent with the serum values obtained in the present parenteral study.

Cs. Cs is closely related to potassium and $\mathrm{Rb}$ in the distribution and excretion pattern, which is similar for these three elements. In an ordinary hospital diet $4^{-18} 8 \mathrm{~g}$ $\mathrm{Cs} / \mathrm{d}$ were supplied (Wester, 1974). This intake range is above the intravenous supply found in all subjects studied.

In oral studies the urinary pathway was found to be the main route of excretion (Boström \& Wester, I968; Wester, 1974). Balance studies (Wester, 1974) sometimes gave negative values similar to those reported in the present study.

$\mathrm{Hg}$. On the evidence at present available, $\mathrm{Hg}$ must be considered a non-essential element for living organisms ( $\mathrm{FAO} / \mathrm{WHO}$ 1973). The average daily intake of $\mathrm{Hg}$ in food by adult man has been estimated at $0.02 \mathrm{mg}$ (Gibbs, Pond \& Hansmann, 194I). An ordinary hospital diet supplies $5^{-27} \mu \mathrm{g} \mathrm{Hg} / \mathrm{d}$ (Boström \& Wester, 1968; Wester, 1974). When the total intake of $\mathrm{Hg}$ is higher than $0.3 \mathrm{mg} / \mathrm{week}$, no more than $0.2 \mathrm{mg}$ $\mathrm{Hg}$ should be present as methyl mercury (FAO/WHO, 1972). This means a maximal tolerable ingestion of $43 \mu \mathrm{g} \mathrm{Hg} / \mathrm{d}$ or $30 \mu \mathrm{g} \mathrm{Hg}$ as methyl mercury/d.

There is wide individual variation in the reported $\mathrm{Hg}$ content in human urine. In forty-six normal human subjects a range of $\mathrm{x}-133 \mu \mathrm{g} \mathrm{Hg} / \mathrm{l}$ urine, with a mean of $23 \mu \mathrm{g}$ $\mathrm{Hg} / \mathrm{l}$ was found (Howie \& Smith, $\mathrm{I}_{967}$ ). However, when applying the neutron activation technique the urinary excretion of $\mathrm{Hg}$ has been reported to vary only from 0.8 to $3.6 \mu \mathrm{g} / 24 \mathrm{~h}$ (Boström \& Wester, 1968; Wester, 1971, 1974).

$R b . \mathrm{Rb}$ is a relatively abundant trace element in the tissues even though it has not been attributed any essential function. $\mathrm{Rb}$, and to a lesser extent, $\mathrm{Cs}$, resemble $\mathrm{K}$ in its pattern of distribution and excretion in the animal body (Glendening, Schrenk \& Parrish, 1956).

An ordinary hospital diet provided $\mathrm{r} \cdot \mathrm{I}-3 \cdot 2 \mathrm{mg} \mathrm{Rb} / \mathrm{d}$ (Boström \& Wester, 1968; Wester, 1974), but in a balance study of two subjects with pancreatic insufficiency, an intake of $3 \cdot 7-6 \cdot 4 \mathrm{mg} \mathrm{Rb} / \mathrm{d}$ has been recorded (Wester, $\mathrm{r} 97 \mathrm{I}$ ). The higher levels of $\mathrm{Rb}$ intake were usually associated with a retention of $\mathrm{Rb}$ whereas the lower levels resulted in negative balances. The urinary excretion of $\mathrm{Rb}$ is generally predominant, but a faecal excretion up to $4.6 \mathrm{mg} \mathrm{Rb} / \mathrm{d}$ higher than the urinary excretion has been found 


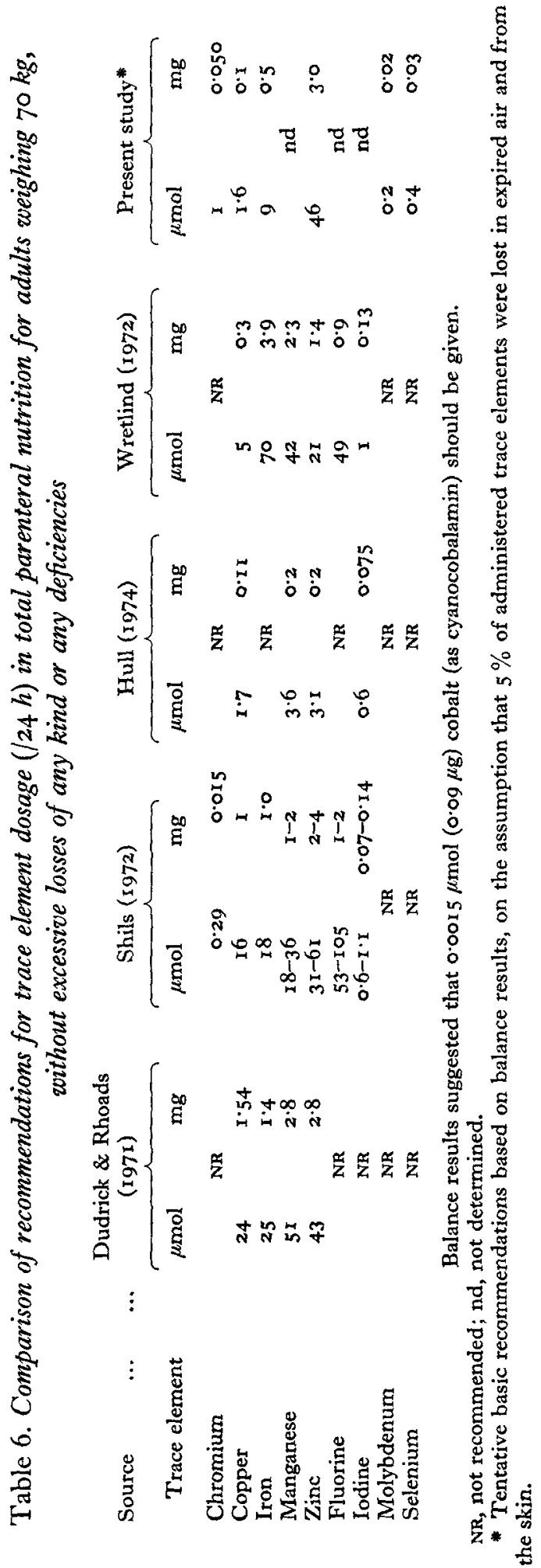


(Wester, 1971). However, in hypertensive patients given a diuretic drug, chlorthalidone, the urinary excretion of $\mathrm{Rb}$ increased significantly, up to $3.9 \pm \mathrm{r} \cdot 2 \mathrm{mg} / 24 \mathrm{~h}$ (Wester, 1973).

$S b$. An ordinary hospital diet supplies $2-18 \mu \mathrm{g} \mathrm{Sb} / \mathrm{d}$, but up to $65 \mu \mathrm{g} \mathrm{Sb} / \mathrm{d}$ has been found (Boström \& Wester, 1968; Wester, I97I, 1974). The parenteral supply was found to be within the same range. In oral studies the faecal route was found to be the predominant way of excretion (Boström \& Wester, 1968; Wester, 1974), whereas in the present parenteral study the main proportion of the Sb excreted was found in the urine. A high supply of $\mathrm{Sb}$ resulted in substantial retention (Wester, 1971). In the present parenteral study the retention of $\mathrm{Sb}$ was approximately that of normal subjects (Wester, 1974).

\section{Trace elements unlikely to be essential for man or animals}

$L a$. In the ordinary hospital diet $\mathrm{I}-8.6 \mu \mathrm{g} \mathrm{La} / \mathrm{d}$ were supplied (Boström \& Wester, I968; Wester, 197 r). The parenteral administration was, however, found to be below this range.

In oral balance studies, frequently a retention of $\mathrm{La}$ is found (Boström \& Wester, 1968). In the present parenteral study two subjects, $A$ and $C$, had slight retention, 0.30 and $0.21 \mu \mathrm{g} \mathrm{La} / \mathrm{d}$ respectively.

Sc. An ordinary hospital diet supplies 0.02-1.1 $\mu \mathrm{g} \mathrm{Sc/d}$ (Boström \& Wester, 1968; Wester, 1971, 1974). The parenteral administration of Sc was found to be within the same range.

Normal serum concentration of Sc up to $0.16 \pm 0.22 \mathrm{ng} / \mathrm{ml}$ have been reported (Wester, I973). In the parenteral study, all the serum values were below the normal average.

Sm. An ordinary hospital diet supplies 2-130 $\mu \mathrm{g} \mathrm{Sm} / \mathrm{d}$ (Boström \& Wester, I 968 ; Wester, 1971). The intravenous administration was found to be approximately the lower limit of the dietary range.

\section{Recommendations}

(US) National Research Council (r 974) recommend only I, Fe and $\mathrm{Zn}$ to be included regularly in the diet. The other trace elements are supposed to be administered in adequate amounts in the variety of common foods eaten. However, in long-term total parenteral nutrition, without an extra supply of trace elements, deficiencies may arise, particularly in patients with increased losses of any kind.

The recommendations for trace element dosage in total parenteral nutrition advocate, instead of the practice of providing these in the form of plasma twice weekly (Jarrett, 1974), the more elaborate supply of a special trace element solution (Jacobson \& Wester, 1973; Grotte et al. 1976). There are also discrepancies in the recommendations (Table 6) (Hamann, 1974). However, it is most important to recognize the requirement of trace elements in parenteral nutrition (Wretlind, 1974).

The results presented suggest that the trace element solution used in total parenteral nutrition might be improved if it supplied rather more $\mathrm{Zn}$ and less $\mathrm{Fe}$, so as to cover the basic requirements more appropriately (Table 3 ). Otherwise, the types and 
quantities of infusion solutions used in the total parenteral nutrition studied seem to supply adequate basic amounts of trace elements, essential for human nutrition ('Table I).

Based on the balance results some tentative recommendations will be given in Table 6, for the basic administration of trace elements to adults without unusual losses or any deficiencies. However, the supply of Cu could probably be increased to $300 \mu \mathrm{g} / \mathrm{d}$ and that of $\mathrm{Fe}$ to $\mathrm{I} \mathrm{mg} / \mathrm{d}$ with respect to the serum concentrations found.

\section{REFERENCES}

Allaway, W. H., Kubora, J., Losee, F. \& Roth, M. (1968). Archs envir. Hlth 16, 342.

Barnes, P. M. \& Moynahan, E. J. (1973). Proc. Royal Soc. Med. 66, 327.

Bergström, K., Blomstrand, R. \& Jacobson, S. (1972). Nutr. Metab. 14, Suppl., I 18.

Blincoe, C. (r960). Nature, Lond. x86, 398.

Boström, H. \& Wester, P. O. (1968). Acta med. scand. r83, 209.

Bowen, H. J. M. (1959). Biochem. F. 73, $3^{81}$.

Brune, D., Samsahl, K. \& Wester, P. O. (1966). Clin. chim. Acta. 13, 285.

Burk, R. F. Jr., Pearson, W. N., Wood II, R. P. \& Viteri, F. (1967). Am. F. clin. Nutr. $20,723$.

Christensen, H. N., Wilber, P. B., Coyne, B. A. \& Fisher, J. H. (1955). F. Clin. Invest. 34, 86.

de Renzo, E. C., Kaleita, E., Heytler, P. G., Oleson, J. J., Hutchings, B. L. \& Williams, J. H. (1953a).

F. Am. Chem. Soc. 75, 753.

de Renzo, E. C., Kaleita, E., Heytler, P. G., Oleson, J. J., Hutchings, B. L. \& Williams, J. H. (1953 b). Arch. Biochem. Biophys. 45, 247.

Dubach, R., Moore, C. V. \& Callender, S. (1955). F. Lab. clin. Med. 45, 599.

Dudrick, S. J. \& Rhoads, J. E. (1971). F. Am. med. Ass. 215, 939.

Dunlap, W. M., James III, G. W. \& Hume, D. M. (1974). Ann. Intern. Med. 80, 470.

Engel, R. W., Miller, R. F. \& Price, N. O. (1966). In Zinc metabolism, p. 326 [A. S. Prasad, editor]. Springfield, Illinois: C. C. Thomas.

FAO/WHO (1972). Tech. Rep. Ser. Wld Hlth. Org. no. 505.

FAO/WHO (1973). Tech. Rep. Ser. Wld Hlth. Org. no. 532.

Foley, B., Johnson, S. A., Hackley, B., Smith, J. C. Jr 8 Halsted, J. (I g68). Proc. Soc. exp. Biol. Med. 128,265 .

Freeman, J. B., Stegink, L. D., Meyer, P. D., Fry, L. K. \& den Besten, L. (1975). F. Surg. Res. I8, 463.

Friberg, L., Piscator, M., Nordberg, G. \& Kjellström, T. (1974). Cadmium in the environment. 2 nd edn. Cleveland, Ohio: CRC Press, Inc.

Ganther, H. E. \& Baumann, C. A. (1962). F. Nutr. 77, 408.

Gibbs, O. S., Pond, H. \& Hansmann, G. A. (1941). F. Pharmacol. 72, 16.

Glendening, B. L., Schrenk, W. G. \& Parrish, D. B. (1956). F. Nutr. 60, 563.

Grotte, G., Jacobson, S. \& Wretlind, A. (1976). In Total Parenteral Nutrition, p. 335 [J. E. Fischer, editor]. Boston: Little, Brown \& Co.

Halsted, J. A., Smith, J. C. Jr. \& Irwin, M. I. (1974). F. Nutr. 104, 345.

Hamann, M. A. (1974). Am. F. Hosp. Pharm. 3I, 1035.

Hart, E. B., Steenbock, H., Waddell, J. \& Elvehjem, C. A. (1928). J. biol. Chem. 77, 797.

Hawkins, W. W. (I964). In Nutrition $-A$ Comprehensive Treatise, p. 309 [G. H. Beaton, editor]. New York: Academic Press.

Henkin, R. J. (1974). N. Engl. J. Med. 29x, 675.

Henkin, R. I., Schechter, P. J., Hoye, R. \& Mattern, C. F. T. (197I). 7. amer. med. Ass. 2 I7. $_{434 .}$

Holmberg, C. G. \& Laurell, C. B. (I947). Acta chem. scand. x, 944.

Hopkins, L. L. Jr (1965). Am. F. Physiol. 209, 73 I.

Howie, R. A. \& Smith, H. (1967). F. forens. Sci. Soc. 7, 90.

Hull, R. L. (1974). Am. F. Hosp. Pharm. 3I, 759 .

Imbus, H. R., Cholak, J., Miller, L. H. \& Sterling, T. (1963). Archs. envir. Hlth 6, 286.

Ingalls, R. L. \& Johnston, F. A. (1954). F. Nutr. 53, 35 I.

Jacobs, A., Miller, F., Worwood, M., Beamish, M. R. \& Wardrop, C. A. (1972). Br. med. F. 4, 206.

Jacobson, S. ( I 972). Nutr. Metab. I4 Suppl., r 50.

Jacobson, S. \& Wester, P.-O. (1973). Näringsforsk. Fräg. 17, 92.

Jacobson, S. \& Wretlind, A. (1970). In Body Fluid Replacement in the Surgical Patient, p. 334 [C. L. Fox Jr and G. G. Nahas, editors]. New York: Grune \& Stratton, Inc.

Jacobson, S. \& Wretlind, A. (1976). In Current Topics in Critical Care Medicine, p. I6I [W. C. Shoemaker and B. M. Tavares, editors]. Basel: S. Kargar. 
James, B. E. \& MacMahon, R. A. (1970). Med. F. Aust. 57, part II, I I6r.

Jarrett, F. (1974). Progr. Surg. 13, I25.

Karpel, J. T. \& Peden, V. H. (I972). F. Pediat. 80, 32.

Keilin, D. \& Mann, T. (1 939). Nature, Lond. 144, 442.

Kubota, J., Lazar, V. A. \& Losee, F. (I968). Arch. environm. Hlth. 16, 788.

Lopez, P. L., Preston, R. L. \& Pfander, W. H. (1969). F. Nutr. 97, r23.

Louria, D. B., Joselow, M. M. \& Browder, A. A. (1972). Ann. intern. Med. 76, 307.

McCance, R. A. \& Widdowson, E. M. (1942). Biochem. F. 36, 692.

McNair, T. J. \& Dudley, H. A. F. (1959). Lancet, ii, 365 .

Mertz, W. (1969). Physiol. Rev. 49, 163.

Mitman, F. W., Wolf, W. R., Kelsay, J. L. \& Prather, E. S. (1975). F. Nutr. 105, 64.

Murphy, J. V. (1970). Ұ. Am. med. Ass. 212, 2119.

National Research Council (1974). Recommended Dietary Allowances, 8th ed. Washington, D.C.: National Academy of Sciences.

Nielsen, F. H. \& Sandstead, H. H. (1974). J. clin. Nutr. 27, 515.

Perry, H. M. Jr. \& Perry, E. F. (1959). F. clin. Invest. 38, 1452.

Pories, W. J. \& Strain, W. H. (1966). In Zinc metabolism, p. 378 [A. S. Prasad, editor]. Springfield, Illinois: C. C. Thomas.

Prasad, A. S. (1966). In Zinc metabolism, p. 250 [A. S. Prasad, editor]. Springfield, Illinois: C. C. Thomas.

Prasad, A. S. \& Oberleas, D. (1970). 7. Lab. clin. Med. 76, 4r6.

Richert, D. A. \& Westerfeld, W. W. (1953). F. biol. Chem. 203, 915.

Saferin, E. H. \& Winne, B. E. (1975). Dis. Colon. Rectum. 18, 134.

Sandstead, H. H., Burk, R. F., Booth, G. H. Jr \& Darby, W. J. (I970). Med. Clins. N. Am. 54, I 509.

Schroeder, H. A., Balassa, J. J. \& Tipton, I. H. (1 962). F. Chron. Dis. 15, 941.

Schroeder, H. A. \& Nason, A. P. (1974). F. Nutr. 104, I67.

Schwarz, K. (1975). In Proceedings of the ninth International Congress of Nutrition, Mexico, 1972. vol. I, p. 96 [A. Chavez, H. Bourges \& S. Basta, editors]. Basel: S. Karger.

Shils, M. E. (1972). Drug. Intel. Clin. Pharm. 6, 385 .

Smith, J. C. \& Kench, J. E. (1957). Br. F. Ind. Med. 14, 240.

Smith, J. C. Jr., McDaniel, E. G., Fan, F. F. \& Halsted, J. A. (1973). Science 181, 954.

Spencer, H. \& Samachson, J. (1970). In Trace Element Metabolism in Animals. Proceedings of WAAP/IBP international symposium, Aberdeen, r969. p. 3r2. [C. F. Mills, editor]. Edinburgh: E. \& S. Livingstone.

Sullivan, J. F. \& Heaney, R. P. (1970). Am. F. clin. Nutr. 23, 170.

Thompson, J. N. \& Scott, M. L. (1969). F. Nutr. 97, 335 .

Thompson, J. N. \& Scott, M. L. (1970). F. Nutr. 100, 797.

Tipton, I. H., Stewart, P. L. \& Martin, P. G. (1966). Hlth Phys. 12, 1683.

Todd, W. R., Elvehjem, C. A. \& Hart, E. T. (1934). Am. F. Physiol. ro7, 146.

Tribble, H. M. \& Scoular, F. I. (1954). F. Nutr. 52, 209.

Underwood, E. J. (editor) (r971). Trace Elements in Human and Animal Nutrition, 3rd ed. New York: Academic Press.

Underwood, E. J. \& Filmer, J. H. (1935). Aust. vet. F. Ir, 84.

Vallee, B. L. \& Gibson, J. G. (1949). Blood, 4, 455.

Vallee, B. L., Wacker, W. E. C., Bartholomay, A. F. \& Hoch, F. L. (1957). N. Engl. Y. med. 257, 1055.

Volkov, N. F. (1963). Fedn Proc. Fedn Am. Socs exp. Biol. 22, T897.

Walker, B. E., Dawson, J. B., Kelleher, J. \& Losowsky, M. S. (1973). Gut, 14, 943.

Wester, P. O. (1971). Acta med. scand. r9o, I55.

Wester, P. O. (1973). Acta med. scand. 194, 505.

Wester, P. O. (1974). Atherosclerosis, 20, 207.

Wester, P. O., Brune, D. \& Samsahl, K. (I964). Int. F. appl. Radiat. Isotopes. 15, 59.

Wolff, H. P. (1956). Klin. Wschr. 34, 409.

Wretlind, A. (1972). Nutr. Metab. I4, Suppl., r.

Wretlind, A. (1974). In Parenteral Nutrition in Acute Metabolic Illness, p. 353 [H. A. Lee, editor]. London and New York: Academic Press.

Wretlind, A. (1975). Opusc. med. Suppl. XXXIX, II.

Yousef, M. K., Coffman, W. J. \& Johnson, H. D. (I968). Nature, Lond. 2r9, Ir73. 